\title{
EVALUASI KINERJA KEPALA SEKOLAH DASAR NEGERI DI KECAMATAN AIR KUMBANG BERDASARKAN BEBAN KERJA SESUAI DENGAN PERATURAN PEMERINTAH
}

\author{
Liskayani $^{1}$, Muhammad Kristiawan ${ }^{2}$, Tobari $^{3}$ \\ liskayani1983@gmail.com¹,muhammadkristiawan@unib.ac.id², \\ drtobarimsi@gmail.com ${ }^{3}$ \\ SD Negeri 17 Air Kumbang ${ }^{1}$, Universitas Bengkulu ${ }^{2}$, Universitas PGRI Palembang ${ }^{3}$
}

\begin{abstract}
Abstrak: Penelitian ini bertujuan untuk mengevaluasi kinerja kepala SD Negeri di Kecamatan Air Kumbang berdasarkan beban kerja sesuai dengan peraturan pemerintah. Model evaluasi yang digunakan dalam penelitian ini adalah CIPP Model (Context, Input, Process, Product). Teknik analisis data yang digunakan adalah pendekatan kualitatif. Teknik pengumpulan data melalui wawancara, observasi dan studi dokumentasi. Hasil penelitian menunjukkan bahwa 1) context evaluation menyatakan bahwa kepala SD Negeri di Kecamatan Air Kumbang dapat lebih fokus pada tugas manajerialnya sebagai kepala sekolah setelah terbitnya PP No 19 Tahun 2017 ini, sehingga PP Nomor 19 Tahun 2017 ini dinilai responsible terhadap kebutuhan sekolah dasar di Kecamatan Air Kumbang, 2) input evaluation menyatakan bahwa kinerja kepala SD Negeri di Kecamatan Air Kumbang sudah baik walaupun sebagian besar SD Negeri di Kecamatan Air Kumbang masih belum memiliki sumber daya yang memadai. 3) Process evaluation menyatakan bahwa kepala SD Negeri di Kecamatan Air Kumbang dapat mengimlementasikan dengan baik PP Nomor 19 Tahun 2017 ini 4) Product evaluation menyatakan bahwa terdapat hasil kinerja Kepala SD Negeri di Kecamatan Air Kumbang yaitu terjadinya peningkatan akreditasi beberapa SD Negeri di Kecamatan tersebut. Dengan demikian dapat disimpulkan bahwa kinerja kepala SD Negeri di Kecamatan Air Kumbang mengalami peningkatan setelah terbitnya PP Nomor 19 Tahun 2017 ini.
\end{abstract}

Kata kunci: Beban Kerja, Evaluasi, Kinerja Kepala Sekolah, Peraturan Pemerintah, Sekolah Dasar

\section{EVALUATION OF THE PERFORMANCE OF HEADS OF PUBLIC ELEMENTARY SCHOOLS IN AIR KUMBANG DISTRICT BASED ON WORKLOADS IN ACCORDANCE WITH GOVERNMENT REGULATIONS}

Abstract: This study aimed at evaluating the performance of headmaster Public Elementary School in Air Kumbang based on workload in accordance with government 
Liskayani, Muhammad, Tobari. Evaluasi Kinerja Kepala SD...

regulations. The evaluation model used in this study is the CIPP Model (Context, Input, Process, Product). The data analysis technique used was qualitative approach. The techniques of collecting data were interviews, observation and documentation. The results obtained indicate that 1) context evaluation stated that the Headmaster Public Elementary School in Air Kumbang could focus more on his managerial duties as headmaster after the issuance of Government Regulations No. 19 of 2017, and it considered responsible for the needs of elementary schools in Air Kumbang; 2) the input evaluation stated that the performance of the Headmaster Public Elementary School in the Air Kumbang was good even though most of the Public Elementary Schools in the Air Kumbang still did not have adequate resources; 3) process evaluation stated that the Headmaster Public Elementary School in Air Kumbang can properly implement PP Number 19 of 2017 ; 4) product evaluation stated that there are performance results of the Headmaster Public Elementary School in Air Kumbang, were the increase in accreditation of several Public Elementary Schools in Air Kumbang. Thus it can be concluded that the performance of the Headmaster Public Elementary School in Air Kumbang has increased after the issuance of Government Regulations No. 19 of 2017.

Keywords: Workload, Evaluation, Principal Performance, Government Regulations, Elementary Schools.

\section{PENDAHULUAN}

Penelitian ini berawal dari terbitnya Peraturan Pemerintah (PP) Nomor 19 Tahun 2017 yang ditandatangani oleh Presiden Republik Indonesia Joko Widodo pada tanggal 30 Mei 2017 dan telah diundangkan oleh Menkumham Yasonna H. Laoly pada tanggal 2 Juni 2017, atas perubahan PP Nomor 74 tahun 2008. Sejak diundangkan oleh Menhumkam, maka PP ini berlaku secara nasional di seluruh Indonesia. Pada PP Nomor 19 tahun 2017 Pasal 54 ayat (1) diterangkan bahwa beban kerja kepala satuan pendidikan sepenuhnya untuk melaksanakan tugas manajerial, pengembangan kewirausahaan, dan supervisi kepada guru dan tenaga kependidikan. Berdasarkan PP ini, tugas seorang kepala sekolah sebagai seorang pendidik bukan untuk melaksanakan pembelajaran di kelas, tetapi sebagai seorang pendidik yang membimbing dan mengarahkan para guru dan tenaga pendidik dalam melaksanakan pembelajaran di kelas.

Hal ini berbeda dengan sebelum PP Nomor 19 tahun 2017 diterbitkan, dimana kepala sekolah adalah seorang guru yang diberi tugas tambahan sebagai kepala sekolah. 
Liskayani, Muhammad, Tobari. Evaluasi Kinerja Kepala SD...

Seperti yang dikemukakan oleh Wahjosumidjo (2002: 83) yang mengartikan bahwa kepala sekolah adalah seorang tenaga fungsional guru yang diberi tugas untuk memimpin suatu sekolah dimana diselenggarakan proses belajar mengajar atau tempat dimana terjadi interaksi antara guru yang memberi pelajaran dan murid yang menerima pelajaran.

Kemudian dalam PP Nomor 74 tahun 2008 pasal 54 ayat (1), dijelaskan bahwa beban kerja kepala satuan pendidikan yang memperoleh tunjangan profesi dan maslahat tambahan adalah paling sedikit 6 (enam) jam tatap muka dalam 1 (satu) minggu atau membimbing 40 (empat puluh) peserta didik bagi kepala satuan pendidikan yang berasal dari Guru bimbingan dan konseling atau konselor. Dengan demikian, pada dasarnya kepala sekolah adalah guru dengan tugas mengajar di kelas setidaknya 6 jam pelajaran perminggu atau membimbing 40 peserta didik, dan diamanatkan untuk melakukan manajerial terhadap pengembangan dan pengelolaan sekolah.

Dalam menjalani tugas di sekolah, maka kepala sekolah harus dapat menjalankan perannya, baik sebagai pendidik (educator), pengelola pendidikan (manager), pelaksana administrasi (administrator), pembina guru (supervisor), pemimpin para guru (leader), pembawa perubahan (inovator), dan pemberi motivasi (motivator). Penguasaan kompetensi ini akan memberi dampak pada kinerja yang dijalankannya (Muzakar: 2014).

Senada dengan tugas kepala sekolah yang termuat dalam Tupoksi kepala SD Negeri di Kecamatan Air Kumbang sebelum PP Nomor 19 Tahun 2017 terbit, dimana kepala sekolah adalah seorang Edukator, Manajer, Administrator, Supervisor, Inovator, dan Motivator. Kepala Sekolah selaku Edukator bertugas melaksanakan proses belajar mengajar secara efektif dan efisien seperti halnya tugas seorang guru yaitu mendidik, mengajar, membimbing, mengarahkan, melatih, menilai dan mengevaluasi peserta didik.

Banyaknya tugas-tugas kepala sekolah terutama sebelum terbitnya PP Nomor 19 tahun 2017 seperti yang telah dikemukakan di atas, membuat kepala SD Negeri di Kecamatan Air Kumbang merasa sedikit kesulitan, terutama untuk membagi waktu antara melaksanakan tugas sebagai seorang guru yang mengajar di kelas dan mengerjakan administrasi sebagai seorang guru dengan menjalankan tugas sebagai seorang kepala sekolah. Apalagi Kecamatan Air Kumbang termasuk daerah perairan 
Liskayani, Muhammad, Tobari. Evaluasi Kinerja Kepala SD...

dengan kondisi jalan yang kurang baik dan jarak yang cukup jauh dari ibukota kecamatan dan ibu kota kabupaten. Kadang kala saat mengajar di kelas, kepala sekolah ditelpon untuk hadir di kantor Dinas Pendidikan, Olahraga dan Pariwisata, hingga terpaksa tugas mengajar di kelas ditinggalkan, sehingga tugas untuk mengajar di kelas tidak dapat terlaksana secara maksimal. Hal tersebut yang dikemukakan oleh Kepala Sekolah SD Negeri 17 Air Kumbang saat diwawancarai oleh Peneliti pada 16 April 2018.

Sebelum terbitnya PP Nomor 19 Tahun 2017, kinerja kepala sekolah dasar di Kecamatan Air Kumbang sudah baik, tetapi masih belum maksimal. Penyebab terjadinya hal ini adalah karena beberapa faktor, seperti terbatasnya anggaran yang diterima oleh sekolah, kurangnya sarana dan prasarana, dan kepala sekolah tidak punya cukup waktu untuk melaksanakan tugas sebagai seorang guru dan tugas manajerial sebagai seorang kepala sekolah (wawancara dengan Pengawas Manajerial kepala SD Negeri di Kecamatan Air Kumbang, H. Ernaldi, S.Pd pada 23 April 2018).

Setelah terbitnya PP Nomor 19 Tahun 2017, beban kerja kepala sekolah menjadi lebih sedarhana. Beban kerja kepala sekolah ini juga diatur dalam Peraturan Menteri Pendidikan dan Kebudayaan (Permendikbud) Nomor 6 Tahun 2018 pasal 15 tentang tugas pokok kepala sekolah ayat (1) yang menjelaskan bahwa beban kerja kepala sekolah sepenuhnya untuk melaksanakan tugas pokok manajerial, pengembangan kewirausahaan, dan supervisi kepada guru dan tenaga kependidikan.

Berdasarkan latar belakang di atas, peneliti memandang perlu untuk melakukan penelitian tetang bagaimana kinerja kepala sekolah di Kecamatan Air Kumbang setelah terbitnya PP Nomor 19 Tahun 2017 yaitu meneliti kinerja kepala sekolah di Kecamatan Air Kumbang dengan tugas sepenuhnya untuk melaksanakan manajerial, pengembangan kewirausahaan, dan supervisi kepada guru dan tenaga kependidikan, tidak lagi dibebani tugas mengajar di kelas setidaknya 6 jam pelajaran perminggu bagi kepala sekolah dari guru kelas atau membimbing 40 peserta didik bagi kepala sekolah dari guru bimbingan dan konseling.

\section{METODE PENELITIAN}

Penelitian ini bertujuan untuk 1) mengetahui bagaimana context evaluation kinerja kepala SD Negeri di Kecamatan Air Kumbang dalam melaksanakan tugasnya 
Liskayani, Muhammad, Tobari. Evaluasi Kinerja Kepala SD...

berdasarkan beban kerja sesuai dengan peraturan pemerintah; 2) mengetahui bagaimana input evaluation kinerja kepala SD Negeri di Kecamatan Air Kumbang dalam melaksanakan tugasnya berdasarkan beban kerja sesuai dengan peraturan pemerintah; 3) mengetahui bagaimana process evaluation kinerja kepala SD Negeri di Kecamatan Air Kumbang dalam melaksanakan tugasnya berdasarkan beban kerja sesuai dengan peraturan pemerintah; dan 4) mengetahui bagaimana product evaluation kinerja kepala SD Negeri di Kecamatan Air Kumbang dalam melaksanakan tugasnya berdasarkan beban kerja sesuai dengan peraturan pemerintah.

Dalam penelitian ini, metode yang digunakan adalah metode deskriptif evaluatif dengan pendekatan kualitatif. Model evaluasi yang digunakan dalam penelitian ini adalah CIPP model. 1) Context evaluation (evaluasi konteks), dilaksanakan untuk menilai kebutuhan, masalah, aset dan peluang guna membantu pembuat kebijakan menetapkan tujuan dan prioritas serta membantu pengguna lain dalam mengetahui tujuan, peluang dan hasilnya; 2) Input evaluation (evaluasi masukan), dilaksanakan untuk menilai alternatif pendekatan, rencana tindakan, rencana staf dan pembiayaan bagi kelangsungan program dalam memenuhi kebutuhan kelompok sasaran serta mencapai tujuan yang ditetapkan; 3) Process evaluation (evaluasi proses), digunakan untuk menilai implementasi dari rencana yang telah ditetapkan guna membantu para pelaksana dalam menjalankan kegiatan dan kemudian akan dapat membantu kelompok pengguna lainnya untuk mengetahui kinerja program dan memperkirakan hasilnya; dan 4) Product evaluation (evaluasi hasil), dilakukan dengan tujuan mengidentifikasi dan menilai hasil yang dicapai, diharapkan dan tidak diharapkan dalam waktu jangka pendek dan jangka panjang, baik bagi pelaksana kegiatan agar dapat memfokuskan diri dalam mencapai sasaran program maupun bagi pengguna lain dalam menghimpun upaya untuk memenuhi kebutuhan kelompok sasaran (Akbar, 2018). Informan dalam penelitian ini adalah seluruh guru, kepala sekolah, serta stake holder SD Negeri Se Kecamatan Air Kumbang yang dapat menjadi key person untuk memberikan informasi akurat terkait penelitian ini.

Tahapan evaluasi yang digunakan adalah tahapan evaluasi yang dikemukakan oleh Stufflebeam (1985), yang meliputi 1) Membuat fokus evaluasi; 2) Mengumpulkan informasi; 3) Mengorganisasikan informasi; 4) Menganalisis informasi; dan 5) Melaporkan informasi. Teknik pengumpulan data menggunakan, observasi, wawancara 
Liskayani, Muhammad, Tobari. Evaluasi Kinerja Kepala SD...

dan dokumentasi. Adapun teknik analisis data menggunakan teknik analisis kualitatif deskriptif. Adapaun langkah langkah analisis data kualitatif pada penelitian ini menggunakan langkah langkah analisis data yang dikemukakan oleh Miles \& Huberman (1986), dimana proses penelitian diawali dengan pengumpulan data melalui observasi, wawancara, dan dokumentasi. Setelah terkumpul, data tersebut direduksi, artinya data tersebut dipilih-pilih mana yang sesuai dengan tujuan penelitian, difokuskan dan disederhanakan. Kemudian data tersebut disajikan dalam bentuk narasi kalimat yang disusun secara logis dan sistematis mengacu pada rumusan masalah. Pada tahap akhir ditariklah kesimpulan atau verifikasi data.

\section{HASIL PENELITIAN}

\section{Context Evaluation}

Context evaluation dalam penelitian ini, bertujuan untuk memberikan perkiraan bagaimana kinerja kepala SD Negeri di Kecamatan Air Kumbang dalam melaksanakan tugas manajerial, kewirausahaan dan supervisi pada PTK setelah terbitnya PP Nomor 19 Tahun 2017 ini. Sehingga dapat diperkirakan apakah PP ini responsif terhadap kebutuhan SD Negeri yang ada di Kecamatan Air Kumbang.

Berdasarkan hasil wawancara dengan Bapak Muhammad Iqbal, S.Pd, M.Pd, selaku Korwil di kecamatan Air Kumbang hingga 4 September 2018, sekaligus selaku pengawas manajerial kepala sekolah sampai sekarang, beliau menyatakan bahwa kinerja kepala SD Negeri di Kecamatan khususnya di bidang manajerial, semakin baik setelah terbitnya PP (Hasil Wawancara Tanggal 6 Agustus 2018). Berdasarkan hasil wawancara dengan Bapak Kaswanto, S.Pd.SD, Kepala SD Negeri 17 Air Kumbang (wawancara tanggal 18 0ktober 2018), Ibu Cik Imah, S.Pd.SD, Kepala SD Negeri 15 Air Kumbang, (wawancara tanggal 5 November 2018), Bapak Sumardi, S.Pd.SD, Kepala SD Negeri 19 Air Kumbang (wawancara tanggal 13 Oktober 2018) dan Bapak Sam'ah, S.Pd M.Si, Kepala SD Negeri 21 Air Kumbang (wawancara tanggal 13 November 2018). Menurut para kepala sekolah ini, sat ini mereka dapat lebih fokus dalam melaksanakan tugas sebagai kepala sekolah, yang berupa tugas manajerial, pengembangan kewirausahaan dan melakukan supervisi pada PTK di sekolahnya masing-masing.

Berdasarkan hasil wawancara dengan Ibu Mego Amrul, S.Pd.SD, Kepala Sekolah SD Negeri 16 Air Kumbang pada 9 Oktober 2018, beliau menyatakan bahwa 
Liskayani, Muhammad, Tobari. Evaluasi Kinerja Kepala SD...

setelah terbitnya PP Nomor 19 Tahun 2017 ini, beliau dapat lebih banyak meluangkan waktunya untuk fokus mengelolah lembaga pendidikan, seperti memutuskan dan mengembangkan visi misi sekolah, mensupervisi PTK, meningkatkan hubungan kerjasama dengan pihak masyarakat melalui komite sekolah dan kegiatan kegiatan manajerial lainnya. Pernyataan di atas, juga didukung oleh hasil wawancara dengan narasumber lainnnya yaitu Ibu Hasnawati, S.Pd, Kepala SD Negeri 18 Air Kumbang (Wawancara Tanggal 11 Oktober 2018); Bapak Sumardi, S.Pd Kepala SD Negeri 19 Air Kumbang (Wawancara Tanggal 13 Oktober 2018), Ibu Sulastri, S.Pd.SD, Kepala SD Negeri 12 Air Kumbang (Wawancara Tanggal 12 Oktober 2018); Ibu Sutinah Christina, S.Pd.SD, Kepala SD Negeri 4 Air Kumbang (Wawancara Tanggal 14 Oktober 2018); Bapak Kaswanto, S.Pd.SD Kepala Sekolah SD Negeri17 Air Kumbang (Wawancara Tanggal 18 Oktober 2018); Bapak Sugeng Sunarman, S.Pd.SD, Kepala SD Negeri 7 Air Kumbang (Wawancara Tanggal 11 Oktober 2018) dan Ibu Cik Ima, S.Pd.SD, Kepala SDNegeri 15 Air Kumbang (wawancara tanggal 5 November 2018) yang juga menyatakan bahwa terbitnya PP Nomor 19 Tahun 2017 sangat membantu kepala sekolah untuk meningkatkan kinerjanya, khususnya kinerja Kepala SD Negeri di Kecamatan Air Kumbang. Oleh karenanya, kepala sekolah tentu menyambut baik PP ini, karena akan memberikan waktu yang lebih banyak untuk mengelolah lembaga pendidikan.

Pada penelitian ini, peneliti tidak hanya menjadikan Korwil, Pengawas, Kabag TU, Staf TU, Ketua KKKS dan Kepala Sekolah pada setiap SD Negeri di Kecamatan Air Kumbang saja sebagai narasumber penelitian. Peneliti juga menjadikan guru pada setiap SD Negeri di Kecamatan Air Kumbang sebagai narasumber. Dari hasil wawancara dengan Bapak Nyamidi, S.Pd, SD, selaku guru SD Negeri 16 Air Kumbang pada tanggal 9 Oktober 2018, beliau menyatakan bahwa dengan adanya PP ini, kepala sekolah saat ini lebih fokus untuk melaksanakan fungsi kepemimpinannya, seperti melakukan supervisi pada guru dan mengajukan pengusulan kenaikan pangkat bagi guru.

Kemudian hasil wawancara dengan Ibu Ulfa Baiti, S.Pd I, guru SD Negeri 15 Air Kumbang, beliau menyatakan bahwa saat ini banyak kepala sekolah di SD Negeri Air Kumbang tidak terkecuali kepala sekolah di SD Negeri 15 Air Kumbang melanjutkan pendidikan ke jenjang S2. Hal ini mengindikasikan bahwa kepala sekolah 
Liskayani, Muhammad, Tobari. Evaluasi Kinerja Kepala SD... juga memiliki waktu untuk melanjutkan pendidikannya setelah tidak dibebani lagi jam mengajar (Wawancara Tanggal 5 November 2018).

Dari hasil wawancara dengan berbagai narasumber di atas, dapat dikemukakan bahwa PP Nomor 19 Tahun 2017 tidak hanya memberikan dampak positif bagi kinerja kepala sekolah akan tetapi juga berdampak baik bagi kinerja guru dan bagi kemajuan sekolah khususnya SD Negeri di Kecamatan Air Kumbang. Oleh karena itu, PP tersebut dinilai responsible terhadap kebutuhan sekolah dasar di Kecamatan Air Kumbang. Meskipun ada beberapa sekolah yang membuat kebijakan untuk tetap memberikan jam mengajar bagi kepala sekolah, akan tetapi secara keseluruhan PP Nomor 19 Tahun 2017 dinilai sesuai dengan kebutuhan sekolah dasar di Kecamatan Air Kumbang.

\section{Input Evaluation}

Input Evaluation dalam penelitian ini bertujuan untuk memberikan gambaran Sumber daya SD Negeri di Kecamatan Air Kumbang berkaitan dengan tujuan PP Nomor 19 Tahun 2017. Berdasarkan hasil observasi dan dokumentasi pada bulan 1 April sampai 31 November 2018, Kecamatan Air Kumbang merupakan wilayah pemerintahan Kabupaten Banyuasin yang berjarak kurang lebih $40 \mathrm{~km}$ dari Kota Palembang Provinsi Sumatera Selatan. Sedangkan jarak Ibukota Kecamatan Air Kumbang dari Pangkalan Balai, Ibukota Kabupaten Banyuasin kurang lebih 120 km.Kecamatan Air Kumbang termasuk sebagai Kecamatan yang dikategorikan daerah perairan. Oleh karenanya, untuk dapat mencapai beberapa sekolah dasar di Kecamatan Air Kumbang harus melalui jalan cukup sulit, terutama di musim penghujan, mengingat masih banyak sekolah dasar yang dicapai harus melalui jalan tanah, jalan setapak atau bahkan menyaberangi sungai, sehingga untuk dapat mencapai ibukota Kecamatan saja kadangkala dibutuhkan waktu beberapa jam (Hasil wawancara dengan Bapak Kaswanto, S.Pd.SD, Ketua KKKS pada 21 November 2018).

Dari hasil observasi, dikemukakan bahwa sebagian besar SD Negeri di Kecamatan Air Kumbang memiliki kondisi jalan yang kurang layak untuk ditempuh dan juga jarak yang cukup jauh untuk ditempuh. Kondisi ini menyebabkan sulitnya bagi kepala sekolah untuk sekedar mencapai ibukota kecamatan atau untuk pembangunan sarana dan prasarana. Oleh karena itu Peneliti juga menilai perlu upaya yang terintegrasi dari segenap pihak terutama kepala sekolah dan stake holder sekolah untuk meningkatkan mutu SD Negeri di Kecamatan Air Kumbang. 
Liskayani, Muhammad, Tobari. Evaluasi Kinerja Kepala SD...

Untuk sarana dan prasarana yang dimiliki oleh SD Negeri di Kecamatan Air Kumbang berdasarkan hasil observasi peneliti, dapat dikemukakan bahwa kualitas sarana dan prasarana pada SD Negeri di Kecamatan Air Kumbang masih dalam kategori rendah. Dari hasil studi dokumentasi dan observasi ada beberapa sekolah yang masih kekurangan ruangan kelas. Berdasarkan hasil pengumpulan data menggunakan dokumentasi, lebih dari 40\% SD Negeri di Kecamatan Air Kumbang mengalami kekurangan ruangan kelas. Ada lima sekolah yang kekurangan satu ruang kelas, ada satu sekolah yang kekurangan dua ruang kelas, ada dua sekolah yang kekurangan tiga ruangan kelas bahkan ada sekolah yang kekurangan sampai empat ruang kelas. Padahal ruang kelas merupakan sarana pokok dalam proses pembelajaran.

Kemudian untuk tingkat pendidikan kepala sekolahnya, terdapat 1 Kepala Sekolah yang berpendidikan Strata 2, sebanyak 20 orang kepala sekolah masih berstatus pendidikan Strata 1. Dari 20 orang kepala sekolah yang berpendidikan Strata 1, terdapat 6 orang kepala sekolah sedang menempuh pendidikan strata 2. Adapun data kepala sekolah dapat dilihat pada diagram berikut.

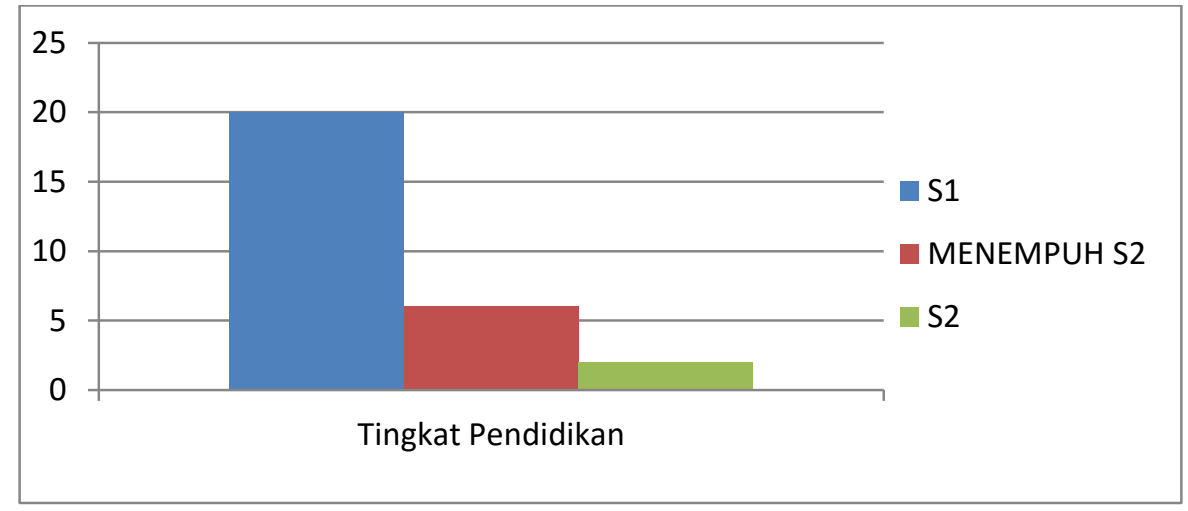

Gambar 1. Data Kepala SD Negeri di Kecamatan Air Kumbang Tahun 2018 Berdasarkan Tingkat Pendidikannya

Dari data di atas, dapat dikemukakan bahwa kepala sekolah di Sekolah Dasar Kecamatan Air Kumbang semakin banyak yang melanjutkan pendidikannya ke jenjang Strata 2, meskipun saat ini sebagian besar kepala sekolahnya masih memiliki tingkat pendidikan Strata 1. Dengan demikian peneliti menilai bahwa Sekolah Dasar di Kecamatan Air Kumbang memiliki sumber daya kepala sekolah yang cukup memadai bila dilihat dari kualitas pendidikannya.

Kemudian dari hasil pengumpulan data melalui dokumentasi, diketahui bahwa 
Liskayani, Muhammad, Tobari. Evaluasi Kinerja Kepala SD...

baru satu orang PTK pada SD Negeri di Kecamatan Air Kumbang yang berpendidikan S2, 148 orang PTK berpendidikan S1, 2 orang PTK berpendidikan D3, 10 orang PTK berpendidikan D2, 77 orang PTKberpendidian SMA sederajat, bahkan terdapat 2 orang PTK yang hanya berpendidikan SMP sederajat. Untuk saat ini, dari 148 PTK yang berpendidikan $\mathrm{S} 1$, ada 3 orang guru yang sedang melanjutkan pendidikan ke jenjang $\mathrm{S} 2$, yaitu satu guru dari SD Negeri 8 Air Kumbang, satu guru dari SD Negeri 17 Air Kumbang dan satu guru dari SD Negeri 18 Air Kumbang. Khusus untuk PTK yang berpendidikan SMP sederajat berstatus sebagai penjaga sekolah. Masih banyaknya PTK pada SD Negeri di Kecamatan Air Kumbang yang belum sarjana tentunya dapat memberikan gambaran bagaimana mutu pendidikan di sekolah tersebut.

Berdasarkan status Kepegawaiannya, jumlah PTK honorer pada SD Negeri di Kecamatan Air Kumbang lebih banyak daripada jumlah PTK yang sudah PNS, baik PNS yang sudah serttifikasi maupun PNS yang belum sertifikasi, diketahui bahwa jumlah PTK PNS yang sudah sertifikasi adalah 82 orang, yang terdiri dari 21 orang kepala sekolah dan 61 orang guru. Untuk PTK PNS yang belum bersitifikasi berjumlah27 orang, sedangkan untuk PTK yang masih Honorer berjumlah 155 orang.

Kemudian hasil observasi peneliti terhadap SD Negeri di Kecamatan Air Kumbang berdasarkan guru berbanding jumlah siswa dapat dilihat pada tabel berikut.

Tabel 2. Jumlah Guru Kelas Berbanding Jumlah Siswa pada SD Negeri di Kecamatan Air Kumbang

\begin{tabular}{|l|l|c|c|c|}
\hline No & Nama Sekolah & Guru Kelas & Siswa & Kategori \\
\hline 1. & SD Negeri 1 Air Kumbang & 6 & 196 & Kurang \\
2. & SD Negeri 2 Air Kumbang & 6 & 105 & sangat \\
3. & SD Negeri 3 Air Kumbang & 12 & 286 & Kurang \\
4. & SD Negeri 4 Air Kumbang & 9 & 210 & Kurang \\
5. & SD Negeri 5 Air Kumbang & 6 & 127 & Kurang \\
6. & SD Negeri 6 Air Kumbang & 6 & 211 & Kurang \\
7. & SD Negeri 7 Air Kumbang & 7 & 275 & Kurang \\
8. & SD Negeri 8 Air Kumbang & 6 & 116 & layak \\
9. & SD Negeri 9 Air Kumbang & 6 & 101 & layak \\
10. & SD Negeri 10 Air Kumbang & 6 & 149 & Kurang \\
11. & SD Negeri 11Air Kumbang & 9 & 135 & layak \\
12. & SD Negeri 12Air Kumbang & 9 & 260 & layak \\
13. & SD Negeri 13 Air Kumbang & 6 & 174 & Kurang \\
14. & SD Negeri 14 Air Kumbang & 6 & 99 & Sangat \\
15. & SD Negeri 15 Air Kumbang & 6 & 136 & Kurang \\
16. & SD Negeri 16 Air Kumbang & 9 & 246 & sangat \\
17. & SD Negeri 17 Air Kumbang & 7 & 213 & Layak \\
18. & SD Negeri 18 Air Kumbang & 8 & 202 & Kurang \\
19. & SD Negeri 19 Air Kumbang & 6 & 141 & Kurang \\
20. & SD Negeri 20 Air Kumbang & 6 & 75 & sangat \\
21. & SD Negeri 21 Air Kumbang & 6 & 74 & sangat \\
\hline
\end{tabular}


Liskayani, Muhammad, Tobari. Evaluasi Kinerja Kepala SD...

Sumber : Hasil Dokumentasi Dapodikdasmen Kecamatan Air Kumbang Tahun 2018.

Dari data di atas, maka dapat diketahui bahwa perbandingan antara jumlah guru kelas berbanding jumlah siswa pada SD Negeri di Kecamatan Air Kumbang adalah 1) terdapat 11 sekolah dasar dalam kategori kurang layak; 2) terdapat 5 sekolah dasar dalam kategori layak; dan 3) terdapat 4 sekolah dalam kategori sangat layak. Adapun kategori tersebut disimpulkan berdasarkan selayaknya seorang guru kelas membimbing 20 orang siswa. Hanya saja pada beberapa SD Negeri di Kecamatan Air Kumbang, guru yang harus membimbing lebih dari 20 orang siswa, bahkan mencapai 39 orang siswa. Jika siswa yang harus dibimbing oleh guru terlalu banyak, tentunya guru tidak bisa menyesuaikan diri dengan kebutuhan masing-masing anak yang berbeda-beda dalam melakukan pembelajaran. Dari hasil observasi tersebut, dapat dikemukakan bahwa sebagian besar SD Negeri di Kecamatan Air Kumbang masih dalam kategori belum layak untuk katagori perbandingan guru kelas dengan siswa.

Dari hasil observasi dan dokumentasi secara keseluruhan pada input evaluation maka dapat dikemukakan bahwa sebagian besar SD Negeri di Kecamatan Air Kumbang masih belum memiliki sumber daya yang memadai. Oleh karenanya cukup berat bagi Kepala SD Negeri di Kecamatan Air Kumbang untuk dapat meningkatkan kinerjanya dalam melaksanakan tugas sebagai kepala sekolah, baik tugas manajerial, kewirausahan maupun melakukan supervisi pada PTK di sekolahnya, jika dibandingkan dengan kinerja kepala SD Negeri di daerah lain yang memiliki sumber daya yang lebih baik daripada sumber daya yang dimiliki oleh SD Negeri yang ada di Kecamatan Air Kumbang. Oleh karenanya sangat tepat apabila kepala SD Negeri di Kecamatan Air Kumbang diberikan ruang yang luas melalui PP Nomor 19 Tahun 2017 ini untuk mengelolah lembaga pendidikannya agar sekolah tersebut dapat meningkat mutu pendidikannya.

\section{Process Evaluation}

Process evaluation dilaksanakan untuk memperoleh informasi mengenai bagaimana kinerja kepala SD Negeri di Kecamatan Air Kumbang dalam mengimplementasikan PP Nomor 19 Tahun 2017 ini, serta untuk menilai apakah PP Nomor 19 Tahun 2017 relatif sukses atau gagal. Dari hasil observasi dan wawancara yang dilakukan oleh peneliti, peneliti menemukan bahwa kinerja kepala SD Negeri di Kecamatan Air Kumbang setelah terbitnya PP Nomor 19 Tahun 2017 ini mengalami 
Liskayani, Muhammad, Tobari. Evaluasi Kinerja Kepala SD...

peningkatan. Hal ini berdampak positif bagi peningkatan mutu SD Negeri di Kecamatan Air Kumbang. Adapun hasil temuan peneliti secara lebih rinci adalah sebagai berikut.

Berdasarkan hasil wawancara dengan Ibu Pariyem, S.Pd.SD, Kepala SD Negeri 3 Air Kumbang pada 29 November 2018, beliau mengungkapkan bahwa di tahun 2018 ini beliau tengah membangun pagar keliling sekolah agar jelas batas-batas tanah milik sekolah dengan menggunakan dana dari komite sekolah, membuat taman agar sekolah tampak lebih indah dan asri, memperbaiki tiang bendera di halaman sekolah dengan menggunakan dana BOS. Hal lain yang dilakukan oleh kepala sekolah adalah memasang rollingdoor di antara ruang kelas. Hal ini beliau lakukan karena sekolah tersebut belum memiliki aula utuk berbagai pertamuan. Selain merehab dan membangun sarana dan prasarana di sekolahnya, Ibu Pariyem ini juga dapat membina para guru dan siswanya meraih berbagai prestasi.

Hasil wawancara peneliti dengan Ibu Mego Amrul, S.Pd.SD Kepala PP Nomor 19 Tahun 2017 kepala sekolah dapat meningkatkan hubungan kerjasama antara pihak sekolah dengan masyarakat melalui komite sekolah, sehingga sekolah dapat menimbum halaman sekolah dengan tanah merah yang dibiayai oleh masyarakat. Sebelum terbitnya PP Nomor 19 Tahun 2017 ini, kepala sekolah tidak memiliki waktu yang cukup untuk melaksanakan kegiatan tersebut, hingga membuat lapangan sekitar sekolah becek dan tergenang air terutama di musim penghujan (Wawancara Tanggal 15 November 2018). Kemudian hasil wawancara dengan Ibu Hasnawati, S.Pd.SD selaku Kepala SD Negeri 18 Air Kumbang, beliau menyatakan bahwa saat ini sekolahnya sedang merehab ruang kelas yang sudah tak terpakai sebagai ruang kantor dan perpustakaan. Karena selama ini sekolah tersebut belum memiliki ruang kantor dan perpustakan (Hasil Wawancara Tanggal 18 November 2018).

Kemudian, hasil wawancara dengan Bapak Sugeng Sunarman, S.Pd.SD,Kepala Sekolah SDNegeri 7 Air Kumbang, yang menyatakan bahwa sejak tidak memiliki beban mengajar di kelas, kepala sekolah dapat fokus mengelolah sekolahnya. Salah satu hasilnya sekolah saat ini dapat membimbing siswanya hingga meraih berbagai prestasi terutama di cabang olah raga dan kepramukan, baik di tingkat kecamatan maupun kabupaten. Selain itu kepala sekolah dapat membuat beberapa lapangan olahraga seperti lapangan bola kaki dan lapangan basket. Dengan pembangunan beberapa lapangan olahraga ini, diharapkan memberikan motivasi bagi para siswa untuk lebih giat berlatih. 
Liskayani, Muhammad, Tobari. Evaluasi Kinerja Kepala SD...

Terutama untuk mempermudah saat melakukan praktek pada pelajaran pendidian jasmani dan olahraga. (Hasil Wawancara Tanggal 7 November 2018).

Dari hasil observasi dan wawancara yang dilakukan oleh peneliti di atas, maka dapat dikemukakan bahwa kepala sekolah dapat meningkatkan mutu lembaganya setelah terbitnya PP Nomor 19 Tahun 2017. Dimana kepala sekolah mampu merencanakan kegiatan dan mampu merealisasikannnya dengan baik. Oleh karenanya PP Nomor 19 Tahun 2017 dapat direalisasikan dengan baik oleh kepala SD Negeri di Kecamatan Air Kumbang.

\section{Product Evaluation}

Product evaluation dalam penelitian ini adalah untuk memberikan gambaran hasil kinerja kepala SD Negeri di Kecamatan Air Kumbang sebagai dampak impelementasi PP Nomor 19 Tahun 2017, serta mengukur efektifitas PP Nomor 19 Tahun 2017 pada SD Negeri di Kecamatan Air Kumbang. Dari hasil pembahasan di atas, dapat diketahui bahwa PP Nomor 19 Tahun 2017 memiliki impact yang cukup besar terhadap peningkatan mutu SD Negeri di Kecamatan Air Kumbang. Berdasarkan hasil dokumentasi peneliti, ditemukan data peningkatan status akreditasi sekolah dasar di Kecamatan Air Kumbang pada periode sebelum terbitnya PP Nomor 19 Tahun 2017 ke periode sesudah terbitnya PP Nomor 19 Tahun 2017. Adapun peningkatan status akreditasi sekolah dasar di Kecamatan Air Kumbang dapat dilihat pada tabel berikut.

\section{Tabel 3. Peningkatan Akreditasi SD Negeri Tahun 2015 sampai 2018}

\begin{tabular}{|c|c|c|c|}
\hline \multirow{2}{*}{ No } & \multirow{2}{*}{ Nama Sekolah } & \multicolumn{2}{|c|}{ Peningkatan Status Akreditasi } \\
\cline { 3 - 4 } & & Akreditasi Tahun 2015 & Akreditasi Tahun 2018 \\
\hline
\end{tabular}


Liskayani, Muhammad, Tobari. Evaluasi Kinerja Kepala SD...

\begin{tabular}{|c|l|c|c|}
\hline 1. & SD Negeri 1 Air Kumbang & C & B \\
2. & SD Negeri 2 Air Kumbang & C & B \\
3. & SD Negeri 3 Air Kumbang & C & B \\
4. & SD Negeri 4 Air Kumbang & C & C \\
5. & SD Negeri 5 Air Kumbang & C & B \\
6. & SD Negeri 6 Air Kumbang & C & B \\
7. & SD Negeri 7 Air Kumbang & B & B \\
8. & SD Negeri 8 Air Kumbang & C & B \\
9. & SD Negeri 9 Air Kumbang & B & C \\
10. & SD Negeri 10 Air Kumbang & B & B \\
11. & SD Negeri 11 Air Kumbang & C & B \\
12. & SD Negeri 12 Air Kumbang & C & B \\
13. & SD Negeri 13 Air Kumbang & C & B \\
14. & SD Negeri 14 Air Kumbang & C & B \\
15. & SD Negeri 15 Air Kumbang & C & C \\
16. & SD Negeri 16 Air Kumbang & C & C \\
17. & SD Negeri 17 Air Kumbang & C & TT \\
18. & SD Negeri 18 Air Kumbang & TT & C \\
19 & SD Negeri 19 Air Kumbang & C & TT \\
20. & SD Negeri 20 Air Kumbang & C & SD Negeri 21 Air Kumbang \\
21 & SD & \\
\hline
\end{tabular}

Sumber : Dokumentasi Dapodikdasmen Kecamatan Air Kumbang Tahun 2018.

Terlepas dari kondisi beberapa sekolah dasar yang masih belum dapat menerapkan atau mengimplementasikan PP Nomor 19 Tahun 2017 secara total dikarenakan beberapa faktor seperti keterbatasan dana yang diterima oleh sekolah, sekolah yang masih kekurangan tenaga pendidik, atau program program kepala sekolah yang masih pada tahap rencana, belum terealisasi namun secara umum usaha kepala SD Negeri di Kecamatan Air Kumbang tersebut dapat menjadi bukti bahwa PP Nomor 19 Tahun 2017 memberikan dampak yang cukup besar terhadap peningkatan mutu sekolah dasar di Kecamatan Air Kumbang. Dengan demikian dapat dikemukakan bahwa keputusan pemerintah untuk menerbitkan PP Nomor 19 Tahun 2017 sudah tepat dan dapat membantu kepala sekolah dalam upaya meningkatkan mutu SD Negeri di kecamatan Air Kumbang.

\section{PEMBAHASAN}

Dari hasil Context evaluation dapat dikemukakan bahwa dengan terbitnya PP Nomor 19 Tahun 2017 merupakan kebijakan pemerintah yang sangat membantu kepala sekolah khususnya untuk fokus melaksanakan tugas menejerialnya (Kristiawan, 2016). Hal ini sesuai dengan kajian manajemen dan supervisi pendidikan yang ditulis oleh Kristiawan dkk (2017) dan Kristiawan dkk (2019). Terbitnya PP Nomor 19 Tahun 2017 sangat membantu meningkatkan kinerja kepala sekolah khususnya SD di Kecamatan 
Liskayani, Muhammad, Tobari. Evaluasi Kinerja Kepala SD...

Air Kumbang. Terbukti setelah terbitnya PP Nomor 19 Tahun 2017, kepala sekolah dapat meningkatkan kinerjanya. Dari hasil wawancara dari berbagai narasumber di atas, dapat dikemukakan bahwa PP Nomor 19 Tahun 2017 tidak hanya memberikan dampak positif bagi kinerja kepala sekolah akan tetapi juga berdampak baik bagi kinerja guru dan bagi kemajuan sekolah khususnya SD Negeri di Air Kumbang. Oleh karena itu, PP tersebut dinilai responsible terhadap kebutuhan sekolah dasar di Kecamatan Air Kumbang. Meskipun ada beberapa sekolah yang membuat kebijakan untuk tetap memberikan jam mengajar bagi kepala sekolah, akan tetapi secara keseluruhan PP Nomor 19 Tahun 2017 dinilai sesuai dengan kebutuhan SD Negeri di kecamatan Air Kumbang.

Kemudian dari hasil input evaluation dapat dikemukakan bahwa sebagian besar Sekolah Dasar di Kecamatan Air Kumbang masih belum memiliki sumber daya yang memadai. Oleh karenanya sangat tepat apabila kepala sekolah diberikan ruang yang luas untuk mengelola lembaga sekolah dasar agar sekolah tersebut dapat meningkatkan mutu pendidikannya. Salah satu cara meningkatkan mutu adalah diperlukan inovasi (Kristiawan dkk 2018). Dengan adanya PP Nomor 19 Tahun 2017, kepala sekolah dapat meluangkan waktu yang cukup dan fokus untuk mengelola sekolah tersebut melalui sumber daya yang dimiliki saat ini.

Hasil process evaluation diketauhi bahwa kepala sekolah dapat meningkatkan hubungan kepala sekolah dengan masyarakat melalui komite sekolah, sehingga sekolah dapat menimbum halaman sekolah dengan tanah merah yang dibiayai oleh masyarakat. Ada kepala sekolah yang dapat membangun pagar dan jalan penghubung antar bangunan di sekolahnya. Ada kepala sekolah yang dapat membangun dapur dan kamar mandi di sekolah sebagai sarana bagi kepala sekolah dan guru yang ingin menginap di sekolah. Ada kepala sekolah yang dapat membangun taman, melakukan pengecatan, dan pembuatan parit untuk saluran air. Kemudian adajuga kepala sekolah yang dapat pemberdayaan ruang kelas yang sudah tak terpakai sebagai kantor, perpustakaan dan ruang UKS yang selama ini belum dapat diperdayakan dengan baik.

Hasil product evaluation menyatakan bahwa PP Nomor 19 Tahun 2017 memiliki impact yang besar terhadap peningkatan mutu SD Negeri di Kecamatan Air Kumbang. Terlepas dari kondisi beberapa SD Negeri yang masih belum dapat menerapkan atau mengimplementasikan PP Nomor 19 Tahun 2017 secara total dikarenakan sekolah 
Liskayani, Muhammad, Tobari. Evaluasi Kinerja Kepala SD...

tersebut masih kekurangan tenaga pendidik, namun secara umum usaha kepala SD Negeri di Kecamatan Air Kumbang tersebut dapat menjadi bukti bahwa PP Nomor 19 Tahun 2017 memberikan dampak yang cukup besar terhadap peningkatan mutu sekolah dasar di Kecamatan Air Kumbang. Dengan demikian dapat dikemukakan bahwa keputusan pemerintah untuk menerbitkan PP Nomor 19 Tahun 2017 sudah tepat dan dapat membantu kepala sekolah dalam upaya meningkatkan mutu sekolah dasar di kecamatan Air Kumbang. Dampak tersebut antara lain adalah meningkatnya kinerja kepala sekolah di Sekolah Dasar Kecamatan Air Kumbang, serta meningkatnya ketergunaan sarana dan prasarana yang selama ini belum dimanfaatkan dengan baik oleh sekolah. Evaluasi harus selalu dilakukan, baik oleh Kepala Sekolah maupun guru guna meningkatkan mutu pembelajaran (Kristiawan dan Elnanda, 2017) (Kristiawan dkk, 2016).

Hasil Penelitian ini didukung oleh penelitian yang dilakukan oleh Aprilianti (2016) dalam hasil penelitian sebagai berikut: 1) Kinerja Dua Kepala SD Negeri di Kecamatan Bringin pada indikator menyusun perencanaan sudah maksimal; 2) Salah satu dari dua kepala sekolah masih kurang maksimal dalam mengembangkan organisasi sekolah. Kepala sekolah belum menempatkan personalia sesuai dengan kemampuannya; 3) Kedua kepala sekolah sudah maksimal dalam memimpin sekolah, menciptakan iklim dan budaya sekolah yang kondusif; serta memonitoring dan mengevaluasi sekolah; 4) Kinerja kepala sekolah dalam memanfaatkan perkembangan teknologi masih kurang maksimal.

Kemudian hasil penelitian ini juga didukung oleh hasil penelitian yang dilakukan oleh Yetri (2014) dengan hasil penelitian menunjukkan bahwa: 1) kinerja kepemimpinan di sekolah sudah dalam katagori baik; 2) prinsip-prinsip kinerja dalam mengelolah perubahan dan pengembangan sekolah dalam katagori baik; 3) prinsipprinsip kinerja dalam menciptakan budaya dan suasana sekolah dalam katagori baik; 4) prinsip-prinsip kinerja dalam menggunakan ICT pembelajaran serta pengelolaan sekolah dalam katagori baik. Selanjutnya hasil penelitian yang dilakukan oleh Aghniya (2017) dalam hasil penelitian menunjukan bahwa gambaran umum dari mutu sekolah dasar di Kecamatan Singkep berada pada kategori tinggi. Sementara kinerja kepala sekolah pada kategori sangat tinggi, dan kinerja mengajar guru pada kategori sangat tinggi. Secara parsial, keduanya memberi pengaruh yang signifikan terhadap mutu 
Liskayani, Muhammad, Tobari. Evaluasi Kinerja Kepala SD...

sekolah. Begitupun jika dilihat secara bersama-sama, kinerja kepala sekolah dan kinerja mengajar guru memberikan pengaruh yang signifikan terhadap mutu sekolah. Hasil penelitian lain yang dilakukan oleh Renata dkk (2018); Andriani dkk (2018); Irmayani dkk (2018); Lian dkk (2018) Murtiningsih dkk (2019) Kristiawan dan Rahmat (2018) Yuliani dan Kristiawan (2017); Aprilana dkk (2017); Kristiawan dan Asvio (2018) Sriwahyuni dan Kristiawan (2019); Tobari dkk (2018) dan Yuliandri dan Kristiawan (2017) ini juga selaras hasil penelitian ini.

Penelitian yang dilakukan oleh Yusuf (2012) dengan hasil menunjukkan bahwa: 1) kinerja kepala sekolah dalam mengimplementasikan pendidikan inklusif berada dalam kategori sedang; 2) kinerja guru kelas dalam mengimplementasikan pendidikan inklusif berada dalam kategori sedang; dan 3) skor kinerja kepala sekolah rata-rata $(65,45 \%)$, lebih tinggi dibanding skor rata-rata yang dicapai guru (62,3\%). Hasil penelitian yang dilakukan oleh Munawir Yusuf ini juga selaras dengan hasil penelitian ini.

Penelitian yang dilakukan oleh Juliantoro (2017) dengan hasil penelitian yang menyatakan bahwa peran kepala sekolah sebagai manajer adalah membuat perencanaan, pengawasan semua kegiatan, penyelesaian semua permasalahan di sekolah, memeriksa semua perlengkapan administrasi, memeriksa semua kelengkapan kegiatan belajar mengajar, sarpras, humas, persuratan, pelayanan rutin perpustakaan, laboratorium, serta administrasi kurikulum.

\section{SIMPULAN}

Context evaluation menyatakan bahwa kinerja kepala SD Negeri di Kecamatan Air Kumbang sebelum terbitnya PP Nomor 19 Tahun 2017 relatif sudah baik dan semakin membaik setelah terbitnya PP ini. Selain kinerja kepala sekolah yang meningkat, kinerja guru juga megalami peningkatan. Oleh karena itu, PP tersebut dinilai responsible terhadap kebutuhan sekolah dasar di Kecamatan Air Kumbang. Meskipun ada beberapa sekolah yang membuat kebijakan untuk tetap memberikan jam mengajar bagi kepala sekolah, akan tetapi secara keseluruhan PP Nomor 19 Tahun 2017 dinilai sesuai dengan kebutuhan SD Negeri di kecamatan Air Kumbang.

Input Evaluation menyatakan bahwa kinerja kepala SD Negeri di Kecamatan Air Kumbang sudah baik walaupun sebagian besar SD Negeri di Kecamatan Air Kumbang 
Liskayani, Muhammad, Tobari. Evaluasi Kinerja Kepala SD...

masih belum memiliki sumber daya yang memadai. Sumber daya yang dimaksud berupa kelengkapan sarana dan prasarana, tingkat pendidikan kepala sekolah dan PTK, pangkat/golongan kepala sekolah, jumlah siswa dalam tiap sekolah yang mempengaruhi jumlah dana yang diterima oleh sekolah tersebut dan lain sebagainya. Ketegori baik untuk kinerja kepala SD Negeri di Kecamatan Air Kumbang ini tentu saja berbeda dengan kategori baik untuk kinerja kepala SD Negeri di tempat lain yang memiliki sumber daya yang tidak sama dengan sumber daya yang dimiliki oleh SD Negeri di Kecamatan Air Kumbang. Sehingga dapat juga dinyatakan bahwa dengan adanya PP Nomor 19 Tahun 2017, kinerja kepala sekolah mengalami peningkatan karena kepala sekolah dapat meluangkan waktu yang cukup dan fokus untuk mengelolah sekolah tersebut melalui sumber daya yang dimiliki saat ini.

Process evaluation menyatakan bahwa kepala SD Negeri di Kecamatan Air Kumbang dapat mengimlementasikan dengan baik PP Nomor 19 Tahun 2017 ini. Hal ini dibuktikan dengan adanya kepala sekolah yang dapat meningkatkan hubungan kerjasama dengan pihak masyarakat melalui komite sekolah, dapat merehab beberapa ruangan kelas di sekolahnya, memberdayakan ruangan yang sudah tak terpakai, melanjutkan pendidikan kejenjang yang lebih tinggi dan sebagainya. Dimana hal ini sebagai salah satu upaya kepala sekolah untuk meningkatkan mutu lembaganya. Oleh karena itu dapat juga dikatakan bahwa PP Nomor 19 Tahun 2017 telah diimplementasikan dengan baik, serta PP Nomor 19 Tahun 2017 relatif sukses dilaksanakan pada SD Negeri Kecamatan Air Kumbang.

Product evaluation menyatakan bahwa terdapat hasil kinerja Kepala SD Negeri di Kecamatan Air Kumbang yang nyata yaitu terjadinya peningkatan akreditasi beberapa SD Negeri di Kecamatan Air Kumbang. Selain itu, ada beberapa hasil kinerja kepala SD Negeri belum nampak karena masih dalam proses ataupun masih pada tahap perencanaan. Mengingat masih mudanya usia PP ini.

\section{SARAN}

Pemerintah tetap memberlakukan PP Nomor 19 Tahun 2017 ini, mengingat PP ini dibutuhkan oleh kepala sekolah terutama kepala SD Negeri di Kecamatan Air Kumbang. Agar kepala sekolah dapat lebih fokus pada kegiatan manajerialnya.

Pemerintah Kabupaten Banyuasin harus memberikan perhatian bagi sekolah 
Liskayani, Muhammad, Tobari. Evaluasi Kinerja Kepala SD...

sekolah yang masih kekurangan tenaga pendidik, sarana dan prasarana agar pelaksanaan PP Nomor 19 Tahun 2017 ini dapat terealisasi dengan maksimal. Dengan demikian kepala sekolah dapat bekerja sesuai dengan fungsinya yaitu tugas manajerial, pengembangan kewirausahaan, dan supervisi.

Agar proses pelaksanaan PP ini tetap dapat berjalan dengan baik perlu disusun juknis pelaksanaannya, mengingat hingga kini belum ada juknis pelaksanaan PP ini. Agar kepala sekolah dan pihak terkait dapat memahami dengan baik PP Nomor 19 Tahun 2017 sehingga kepala sekolah tidak salah menginterpretasikan PP tersebut sebagai keuntungan bagi kepala sekolah karena beban kerjanya berkurang.

Dengan adanya PP Nomor 19 Tahun 2017, Kepala Sekolah Dasar di Kecamatan Air Kumbang dengan segala kelebihan dan kekurangannya baik sarana dan prasarana ataupun tingkat pendidikannya diharapkan mampu bersaing dengan kepala sekolah dari daerah lain dalam upaya meningkatkan mutu pendidikan khususnya Sekolah Dasar di Kecamatan Air Kumbang.

\section{UCAPAN TERIMA KASIH}

Ucapan terima kasih yang sangat besar saya sampaikan kepada Bapak Muhammad Ikbal, M.Pd dan Bapak Filly Hardian, S.Pd, M.Si selaku Korwil Kecamatan Air Kumbang, Bapak Halim, S.E selaku Kabag TU Disdikporapar Kecamatan Air Kumbang, Bapak Kaswanto, S.Pd. SD selaku Ketua KKKS Kecamatan Air Kumbang, seluruh kepala SD Negeri di Kecamatan Air Kumbang serta Narasumber lain yang tidak dapat saya sebutkan satu persatu atas bantuannya memberikan informasi.

\section{DAFTAR RUJUKAN}

Akbar, R, A. (2018). Evaluasi Program Pengembangan Anak Usia Dini Holistik Integratif di Satuan PAUD. AWLADY: Jurnal Pendidikan Anak. Vol 4, No 2: $136-164$.

Aghniya, H. (2017). Kinerja Kepala Sekolah dan Kinerja Mengajar Guru dalam Peningkatan Mutu Sekolah Dasar Negeri. Jurnal Administrasi Pendidikan Vol. XXIV No.1 April 2017.

Aprilianti. (2016). Evaluasi Kinerja Dua Kepala SD Negeri di Kecamatan Bringin Tahun 2015. Tesis Universitas Kristen Satya Wacana.

Juliantoro, M. (2017). Peran Kepala Sekolah dalam Meningkatkan Mutu Pendidikan. Jurnal Al-Hikmah Vol 5 No.2 : 1-13. 
Liskayani, Muhammad, Tobari. Evaluasi Kinerja Kepala SD...

Kristiawan, M. (2016). Filsafat Pendidikan. Yogyakarta: Valia Pustaka.

Kristiawan, M., \& Elnanda, D. (2017). The Implementation of Authentic Assessment in Cultural History of Islamic Subject. Al-Ta lim Journal, 24(3), 266-276.

Kristiawan, M., Suryanti, I., Muntazir, M., \& Ribuwati, A. (2018). Inovasi Pendidikan. Jawa Timur: Wade Group National Publishing.

Kristiawan, M., Yuniarsih, Y., \& Fitria, H. (2019). Supervisi Pendidikan. Bandung: Alfabeta.

Miles, M.B. \& Huberman, A.M. (1986). Qualitative Data Analysis: a Sourcebook of New Methods. California: SAGE Publication Inc.

Muzakar. (2014). Kinerja Kepala Sekolah Dalam Meningkatkan Mutu Lulusan Pada Madrasah Tsanawiyah Negeri Meureubo. Jurnal Ilmiah Islam Futura, Vol. 14. No. 1, Agustus 2014, 110-133.

Peraturan Menteri Pendidikan dan Kebudayaan Nomor 6 Tahun 2018 tentang penugasan guru sebagai kepala sekolah

Peraturan Pemerintah Republik Indonesia Nomor 19 Tahun 2017 tentang guru.

Stufflebeam, D,L. (1985). Educational Evaluation and Decising Making, Illionis: Hasca Illionis Pecocok Publicers Inc.

Wahjosumidjo. (2002). Kepemimpinan Kepala sekolah:Tinjauan Teoritik dan Permasalahannya. Jakarta:Raja Grafindo Persada.

Yetri. (2014). Evaluasi Kinerja Kepala Sekolah Menengah Kejuruan di Kota Bandar Lampung.Jurnal Lentera Pendidikan, vol 18 No.1 Juni 2015: 95-106.

Yusuf, Munawir. (2012). Kinerja Kepala Sekolah Dan Guru Dalam Mengimplementasikan Pendidikan Inklusif. Jurnal Pendidikan dan Kebudayaan, Vol. 18, Nomor 4, Desember 2012. 